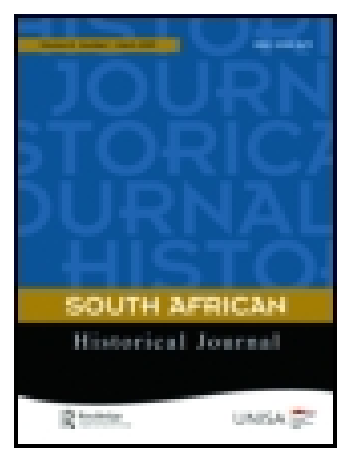

South African Historical Journal

\title{
Conversations with Historians
}

\section{Christopher Saunders \& Cynthia Kros}

To cite this article: Christopher Saunders \& Cynthia Kros (2004) Conversations with Historians, South African Historical Journal, 51:1, 1-23, DOI: 10.1080/02582470409464827

To link to this article: http://dx.doi.org/10.1080/02582470409464827

\section{Published online: 26 Mar 2009.}

Submit your article to this journal $\pi$

山 Article views: 55

Q View related articles $\sqsubset$ 
South African Historical Journal 51 (2004), 1-23

\title{
Conversations with Historians
}

\author{
CHRISTOPHER SAUNDERS and CYNTHIA KROS \\ University of Cape Town and University of the Witwatersrand
}

The editors of the South African Historical Journal decided to commemorate its 51 st issue by asking a range of historians - some established, some emerging - to reflect on the state of the discipline. We present an edited collation below of the answers we received. Some of the responses were written, while others were given in the course of interviews with us, which may account for differences in structure, tone and length. We would like to thank our respondents, and we hope that their contributions will open a debate that will continue in future issues of the Journal.

\section{The state of the discipline today}

Sello Mathabatha (University of the Witwatersrand) is very positive about the surfacing of 'hidden history', and describes 'social historians through oral testimonies and oral traditions bringing more constituencies or communities into the fold'. Some of his colleagues were, however, a little more tentative. Noor Nieftagodien (University of the Witwatersrand) stresses History's loss of critical edge - a lament that finds several echoes elsewhere - and fears that History is being subsumed in the new nationalist narrative:

History was viewed as part of the liberation discourse and movement from the late 1970s. My sense, coming from that tradition, is that History has lost its edge in terms of questioning authority and power. Now History is being mobilised behind a nationalist narrative.

Referring to colleague Peter Lekgoathi's views, he continues: 'I agree with Peter that it's ironic because in other post colonial situations History experienced an upsurge in its fortunes.' He tries to explain the general wariness that people feel about History, often putting what he calls 'an awkward distance' between it and themselves, 'saying things like "the youth isn't really interested in the past"'. He lays some of the blame at the door of the Truth and Reconciliation Commission (TRC), while recognising its considerable cathartic benefits:

The TRC was hamstrung by its mandate so that it had to focus on particular forms of offences. As a history project it didn't critically engage the underlying processes that contributed to apartheid and to change. It worked within the easy binaries of good and evil; 
victim and perpetrator, which foreclosed on any real enquiry into historical processes, including the complexities of causality and effect. Individuals and organisations, even narratives, were pigeonholed as either good or bad. It lacked the kind of complexity proper history can and does provide.

He does concede, however, that the TRC researchers provided a potential 'goldmine' for future research.

Nieftagodien sees hope in some of the urban-renewal projects with which he has been involved, most recently in Alexandra Township. Here he has heard a demand for local history, amplified by the Townships Now symposium hosted by the University of the Witwatersrand's Institute for Social and Economic Research (WISER) in June 2004. 'It might be narrow,' he observes, because the demand is fundamentally a call made by 'people wanting to know about themselves and their particular area' against the background of school history which 'everyone knows (was) only partial and very biased'. But 'we underestimate the extent to which people feel affirmed by knowing that their stories are written'. Nieftagodien sees a 'huge chasm' between the Academy and the demand for local history, not only from Africans in townships, he says, but also - as he has gathered from attending a conference in Brakpan - from other groups such as Afrikaner workers in Ekhurleni. Social history, he maintains, 'is stuck in the old categories: migrants, women and the working class', which are 'critically important', he hastens to add.

But we also need to cast our eyes in different directions, for example towards cultural categories. People want to talk about their involvement in sport (for example), and this could shed new light on kinds of communities. Reference was made in the Townships Now conference by commentators to the people living in the townships and their histories. There isn't that sort of History in the Academy - not many people are addressing the demand. Most often there is still a focus on the political aspects. Township residents are still rendered essentially as political beings. The binary works that if you weren't part of the liberation struggle you were against it. In this binary world there is no place to be in between.

But Nieftagodien does reflect that, as we move further from 1994, this may change.

Peter Lekgoathi (University of the Witwatersrand) strikes a note of optimism about the state of History today, especially as he looks back to the time of his appointment at Wits in 2000, at the beginning of Kader Asmal's term as Minister of Education. Under Asmal's predecessor, History had been consigned to the neoliberals' dustbin. 'In what we would call the previous dispensation,' Lekgoathi recalls, 'History was out. It had actually been phased out of the syllabus and become part of Human and Social Sciences.' This process also coincided with a more general feeling, in Lekgoathi's view, which went along the lines of 'we don't need the past to be a prosperous country, we need technology', and so all the dreams that History would 'flower' after 1994 had temporarily gone. In this sense, 
Thabo Mbeki's government has offered a kind of salvation because it 'realised how important History is to nation-building, civic responsibility and so forth. Hence the emphasis on History, hence the new attitude, hence the Revised National Curriculum Statement for Schools.' Lekgoathi points out that academic History is very dependent on what happens in schools.

As a result of his involvement in the History Workshop's teachers' conferences, Lekgoathi has been in contact with what he says is 'a lot of enthusiasm on the part of educators in the different provinces', especially about oral history. He reflects:

Oral history is a way of bringing in the human element to History, making it alive and interesting, not only for the educators but also for the learners, in line with the new Outcomes Based Education (OBE) that is learner-centred and skills-based. Oral history acknowledges the contributions of the local people in the making of history, contributing to the democratization of the discipline. There is a possibility for educators to hear different voices - not just one voice from a textbook prescribed by the Department of Education.

Like Lekgoathi, Sifiso Nldovu (Africa Institute of South Africa) recalls what he describes as the 'knockout blow delivered by Dr Sibusiso Bhengu, the first Minister of Education in the post-1994 period', and the 'damage control' subsequently introduced by Asmal when he took over from Bhengu, through the creation of the South African History Project, whose advisory committee reported directly to the Minister, and the South African Democracy Education Trust.

Ndlovu points to the 'plethora of historical documentaries and films' currently being shown on SABC television, as well as to radio broadcasts of History programmes, especially about precolonial history, on stations such as Ukhozi FM (formerly Radio Bantu broadcasting in isiZulu). The latter is 'the leading radio station in South Africa in terms of audience, averaging six million listeners'. Ndlovu reminds us of DSTV having 'entered the fray' by securing rights to broadcast the History Channel. Access is limited, however, to those who can afford it. 'There also exist public history projects such as Freedom Park, the Robben Island Museum, the Cradle of Humankind, the Apartheid Museum and the Hector Pieterson Museum, to name a few.'

Ndlovu is adamant, unlike some of the other respondents, that the youth are not disaffected:

I do not buy the idea of the youth of today [not being] into History. I judge this on the type of questions that my son, niece and nephews, [and] their peers ask me about the present. Also, some of my expensive books, particularly about the history of Africa, have disappeared from the bookshelves at home and I am aware of who the culprit is - in fact I end up handing him [my son] eight volumes of the UNESCO History of Africa series in order to quench his thirst because he did not study History at school and is not registered for a formal History course. Again, as a principal researcher at the Hector Pieterson Museum, I make it a point to read through the visitors' comments as a form of feedback 
whenever I visit ... one gets the sense that people are expecting more from professional historians.

Ndlovu longs to be in a position to do a follow-up survey on what has happened to African History students whom he interviewed for his master's dissertation between 1991 and 1992, to evaluate whether or not present careers and developments in their lives are related to their tertiary qualifications in History. 'We all know,' he says, 'that in pre-1994 South Africa the majority of them would have ended up as school History teachers or clerks at a dingy office somewhere at Bantu Affairs'. ' Ndlovu goes on to say: 'I have come across some of these students - one of them is a successful, globetrotting investment banker, and another is a director at one of the well-known museums - both of them were in my first-year History tutorial groups.'

Ndlovu then goes on to remark that History still struggles against adverse forces.

Most school principals, teachers and parents are discouraging students - influencing them not to study History, which is wrongly perceived as a "useless" subject... if I was a PRO ... I would use the public faces of Pallo Jordan, Danny Jordaan, Essop Pahad, Phumzile Mlabo-Ngcuka, amongst others, to promote the study of History. They are all historians in their own right...'.

Natasha Erlank (Rand Afrikaans University), after talking about some of the 'constraints' that currently confront the History profession, stresses that she really likes what she does and points out that 'people who have positions in History are tremendously fortunate'. She bases this judgment on the assumption that, in view of 'overwork, bad salary prospects and low prestige' anyone who chooses History as a profession must 'have a calling', which few are lucky enough to be able to answer. She observes that, for the most part, History continues to be a white and male profession, with a slow turnover of posts being one of the major 'constraints' she cites. Her 'two wishes' for South African History are that 'more women, specifically black women, would come into the profession and practise it', and that historians would cease being monolingual or even bilingual, and would be in a position to study sources in a range of African languages.

Erlank also talks about how she has been tempted to give up working on nineteenth-century history because of 'the lack of peer support on the Highveld. Peer support is very important.' She expresses her 'regret that the role of the professional societies is not what it could be. We are doing disparate things in different parts of the country and many History Departments are too parochial.' She compares the collaborative work she does with scholars Shireen Hassim,

1. See Albert Grundlingh's response below for the connection between tertiary level History and limited professional opportunities for blacks in the pre-1994 period. 
Sheila Meintjes and Cathi Albertyn on contemporary issues related to gender with the 'loneliness of the long time-frame historian'. When she is asked to referee papers for academic journals, Erlank is often conscious that this 'is the first time anyone is working on their stuff' and 'if I want (historical) stuff read it goes to Australia or the Netherlands'. It's not that 'academics want to shut people out,' she says, although she retains an undergraduate memory of a corridor of closed office doors, "but the Academy assumes we ought to be working on our own. This prevailing ethos of the discourse has negative spin-offs in various areas. I wish there could be more collaborative work in History.'

But, in the end, Erlank, as self-conscious historian, takes a long-term view of the state of the discipline. 'There is ebb and flow. Sometimes it's bad. Sometimes it's good. If the tertiary sector can get itself together, and in the bestcase scenario, get more graduate students, then they can set up debates and take things forward.'

Paul Maylam (Rhodes University) is cautiously optimistic. For him, academic history is coming out of the major crisis it faced five years ago, when student enrolments were falling dramatically, but it still remains in the doldrums. 'Far fewer history books are being published than was the case twenty years ago.' Like Nieftagodien, Maylam observes:

History in South Africa seems to have lost much of its political edge. One worries about how the academic profession of historians is going to reproduce itself over the next twenty years. The discipline appears not to be attracting the brightest young minds in the way it used to do. An academic career in history may become a less appealing proposition if the relevance of the discipline is not self-evident - and as the material returns from university teaching continue to decline.

Anne Mager (University of Cape Town) contextualises History's struggles more globally:

The state of History is not only a South African matter. History departments in Britain and elsewhere have also struggled with falling numbers as the long-term effects of Thatcherite thinking dig into the minds of administrators, parents and future generations of scholars. So, there is a kind of global turning away from History to the more remunerative and shallow pastimes of money-making.

Looking at the state of South African history from abroad, Norman Etherington (University of Western Australia) seems to think that South Africa is out of the global step. He believes that historical studies here lack a clear sense of direction and purpose:

I have no sense of a scholarly agenda of questions requiring urgent answers. Attempts to re-orient South African history either externally or internally have met with little positive response. Globalisation and the rise of world history have stimulated historians to make 
fundamental reappraisals elsewhere in the world, but not - so far as I am aware - in South Africa.

Etherington wonders if is not time for history in the academy and the schools 'to take more notice of work done outside the fields of South African and African history (USA, Europe, Latin America, South and East Asia)'.

Albert Grundlingh (University of Stellenbosch) is concerned to make the point that the exponential growth in student numbers that supported healthy ratios of teaching staff in university History departments in the 1980s was artificial in the sense that it was 'boosted by apartheid'. Structural limitations on job opportunities for black graduates caused many to gravitate towards teaching as a career, with History proving to be a popular major. Promotional incentives offered to teachers also prompted many to register for higher tertiary qualifications. Acknowledging that he is slightly 'oversimplifying matters', Grundlingh maintains that 'interest in history could be bought'. ${ }^{2}$ Nevertheless, in an observation that sheds light on Noor Nieftagodien's memories of undergraduate History, Grundlingh points to what he calls the 'creative misuse' to which skilled History educators could put their material in those days, so that it 'ran against the apartheid grain'. He stresses that History could be used both in the cause of legitimising the apartheid state, and in resisting it. It was, he implies, inevitable that History should 'fall off in the 1990s', especially under the pressure of the 'market-driven' creed which did not recognise the value of History as 'product', new professional opportunities for an aspirant black middle class, the unfavourable design of the new school curriculum, and, in general, "the growing gap between what the Academy had to offer and what the state required'. He also comments that History is for 'the mature mind', observing that it only really makes sense to those who have 'lived a little and come to terms with their own identity'. Grundlingh compares the current 'Nike generation', obsessed with fashion and culture, to the older, more politically orientated generation of the $1980 \mathrm{~s}$. But, he also points out that a return to the $1980 \mathrm{~s}$ is hardly desirable, since it was based on an essentially 'unsound' foundation. Like some of the other historians represented here, he imagines a gradual 'growth' of the discipline on the basis of firmer principles; he also talks about edging 'towards a more inclusive narrative'. ${ }^{3}$

For John Wright (University of KwaZulu-Natal, Pietermaritzburg), the main issue is 'whether we can still see the discipline of academic history in South Africa today in the singular':

I say 'still', because for most of the century-long history of the discipline in this country academic historians, in their different and often fiercely opposed schools, seem to have had

2. A. Grundlingh, 'Some Trends in South African Academic History', in S. Jeppie, ed., Toward New Histories for South Africa (Cape Town, 2004).

3. Ibid. 
a fairly clear idea of what they ought to be doing, what they wanted to be doing, and how they should do it. In spite of pronounced ideological and political differences among them, they shared a broad, strongly positivist view of what history was, and how it should be researched and written. The discipline was installed in South Africa by European or European-trained academics in the early twentieth century when views of this kind were overwhelmingly dominant; it developed in a colonial milieu where there was little to trouble them. In the post-colonial climate of today, as has been commented on often enough, the unity of the discipline is unravelling. Many established historians, probably the majority, continue to plug away at teaching and researching in the ways they are used to, but numbers of them are no longer as sure as they used to be why they are doing it. Others, particularly in the fields of heritage studies and of environmental history, are breaking important new research ground, and, at least in the case of heritage studies, important new conceptual ground as well. A few are wondering whether, in the 'post-modern' twenty-first century, there will be a place for a discipline whose ways of making meaning of the past were developed in the part of the 'modernist' era which extended from the mid-nineteenth century to the mid-twentieth.

Leslie Witz (University of the Western Cape), in common with others, comments on the continuing 'difficulties' associated with generally low student numbers in History, and to the pressure on staff to 'teach elsewhere in other programmes and disciplines to reinvent themselves in some way', and does not see the 'trend' as finally abating even now. 'When I came to UWC in 1990 there were 3000 undergraduate students in History, now there are somewhere between 200 and 300.' He attributes the loss of students to the Education Department, as others have done, and to the cessation of bursaries for students following courses approved for teacher qualifications. In retrospect he wonders whether Colin Bundy's argument about the 'appetite for the past' during the liberation struggle was accurate:

It could have been Colin's misreading or our misreading. Was there an appetite? Or was it our imagination? At the time it seemed to be there. Whether or not it was there and whether it translated into numbers of students are two different things. It was translated through the bursary system. People were using History. Some of the people in power now have had History training - looking at my former students. There certainly was a sense at the time that History was necessary politically.

Like Wright, Witz does see a productive breaking of new conceptual ground. Thus he claims:

In terms of the Heritage industry, let's call it, History is still very strong. That has become more evident recently in Heritage products like the Fort [on Johannesburg's Constitution Hill], bringing in a more critical edge to Heritage. It's a good thing with people like Phil Bonner and Noor Nieftagodien being involved. The UWC/UCT/Robben Island Museum Postgraduate Diploma in Museum and Heritage Studies is taking off again. Students from all over the continent are coming to the programme. And that's become another route into History. We're getting students at UWC from Museum Studies going into History at 
master's level (in Public and Visual History) and some of the best students have come out of that route. They have often had the experience in the field already, but need the theoretical and conceptual material to enable them develop their critical understanding of historical issues.

\section{Heritage and history}

While Mathabatha characterises the relationship between History and Heritage as mutually beneficial, with few qualifications, most of the other historians surveyed and interviewed had decidedly mixed feelings about what they tend to see as the encroachment of Heritage.

Maylam, in common with several others, points out that it is necessary to distinguish between the heritage industry and heritage studies:

The former represents, at worst, a crude commoditisation and commercialisation of history - a process by which the past becomes neatly packaged and fixed in simplistic ways. Heritage studies can provide a necessary critique of this process. However, the heritage industry seeks input from historians and draws upon their work. Historians both supply materials and critique the way in which they are used. So the relationship between heritage and the academic sector is a delicate one. One cannot be over-critical of the heritage sector because by its very nature it will tend to simplify the past. It would be dangerous for the history profession to invest too much energy in the heritage sector in the belief that this would be the best hope for the survival of the discipline. Heritage studies should be viewed as just one of many branches or sub-disciplines in the field of history and should not be accorded special status.

\section{Etherington agrees:}

History is one thing, Heritage Studies are something else. In Australia I have done a great deal of work in heritage, none at all in South Africa. The study of heritage is always tugged in the practical direction and only rarely stimulates important theoretical or historiographical debates. Heritage studies are always in the market place, even when they attempt to offer subversive or unpopular insights.

Nieftagodien, on the other hand, describes how hard it has become for a historian to be 'just a historian' in the 'new liberal world', and how Heritage offers more prestige, a longer title - 'Heritage Practitioner' - and a better profile:

Heritage is more sexy. You can't survive as a historian unless you outsource yourself. You have to do five or six things to be acknowledged. Your peers can't believe that you're simply a historian. They can't see the value. You've got to do something to contribute to society. From the point of view of the public, Heritage is more important than History.

He confesses, however, that he is not sure what he really thinks of Heritage in the end, and describes a good deal of vacillation. 'The flourishing of Heritage? My 
mind changes by the day.' He recognises some of its symbolic importance, but quickly goes on to stress that the best heritage practices are those that invite critical engagement. He also castigates historians who are not willing to dirty their hands by involving themselves in heritage projects, observing that then they 'cede ground to problematic interpretations of the past', exemplified so far, he thinks, in the Freedom Park project in Pretoria. 'Heritage shouldn't be left to people who think Heritage is picking out iconic events or symbols', or 'following a political agenda that is averse to critical interpretations of the past'. But there are other instances in which dynamic collaboration between historians and heritage practitioners has borne fruit, and Nieftagodien cites Constitution Hill in Johannesburg as an example, as well as some of the projects in which the 'UWC people have engaged critically to give a different meaning to Heritage'. Despite Heritage's 'inherent tendency not to engage the past critically', there are sites in which 'synergies' with historians are creating versions of the past that are quite far removed from the 'dominant narrative', and in which history 'is not disconnected from ordinary people's experiences and needs'. For Nieftagodien, this is the most positive meaning of 'social history'. He recognises that there will always be distinctions between professional historians and 'ordinary people' which are not miraculously erased through interaction in the field. But he does believe that writing the history of ordinary people helps to deliver history that 'cuts across the nationalist grain'.

Ndlovu is reluctant to offer 'an expert comment on this issue', because he is 'no longer a History lecturer at a higher-education institution'. Nevertheless, he says that he defines research, such as that he has undertaken for the Hector Pieterson Museum, as Public History. He refers to a wide variety of 'forms of History' in which he is engaged: 'Oral, Public, Precolonial, Youth in History, and lately Contemporary History through the South African Democracy and Education Trust (SADET) Project'. Ndlovu stresses that he adopts 'the same academic rigour, methods and methodology' when he is researching issues involving Public History as he does in the other cases.

Ndlovu is wary of tourism if the personnel have not been 'grounded in History as a discipline', and recalls an unfortunate incident which occurred three years ago when he was taking a group of graduate students from the USA around Soweto. Ndlovu had to intervene because the so-called professional tour-guide accompanying the party embarked on a narrative that was 'ahistorical, littered with racism, tribalism and embellishments'.

Lekgoathi reflects on how History and Heritage have collided in the work he has been doing for his doctoral thesis on Ndebele ethnicity. Like Nieftagodien, in his characterisation of 'the easy binaries', Lekgoathi has come up against the dichotomies of good and evil, as well as politically entrenched romanticisation of a timeless Ndebele unity in the North, which he feels obliged, as a historian, to challenge. 'Heritage,' he observes, 'is about myth-making', and in his thesis, the 1854 siege of what was called 'Makapansgat' (Gwasa Cave, to the North Ndebele- 
speaking Kekana whose ancestors were the victims of the siege), looms large as a very powerful site of mythology. It is recalled 'as one of the sites where black people actually resisted white domination, and there is an emphasis on Afrikaner brutality' (just as in the Afrikaner version of the story, as Lekgoathi reminded us later, there used to be an emphasis on black savagery to justify the cruelty of the siege), and 'African victimology'. There is no room, Lekgoathi points out, for 'the complexities I' $m$ interested in as a historian. There is no simple division between victim and perpetrator.'

Lekgoathi says that 'with the development of North Ndebele', as the product of a cultural revivalist movement in response to perceptions of constitutional exclusion in the new South Africa, "comes also a new way of reimagining North Ndebele identity and history. The story of the Cave is at the centre of this new reimagining of identity.' He alludes to the founding of choirs from 2000 onwards by 'cultural activists' from the North AmaNdebele National Organisation (NANO), at least one of whom is located in Moshate, the current Kekana centre. He refers to some of the lyrics composed by a 'cultural activist' to illustrate what he is saying about the centrality of the siege to North Ndebele revivalism: "The Cave of Gwasa where our ancestors were killed by the Boers, this is their final resting place. This is where they showed their heroism against Boer oppression.' Another song is about the unity of the different Ndebele chiefdoms in the North: 'We are the Ndebele of Langa, of Kekana, of Masasane, of Mokopane, we are one in order to fight the struggle for recognition together.' Another song is about the need for the Ndebele to be recognised, at least at a provincial level: 'We are Venda, Tsonga, Pedi and we are also Ndebele, so Ramathlodi [the former premier of Limpopo] should recognise us as such'.

As Lekgoathi has learnt to his cost, the historian who produces a more historical account of 'North Ndebele' identity is likely to find her/himself at the centre of a heated debate. Lekgoathi recalls addressing a meeting of North Ndebele activists at Funda Centre in Soweto:

We need to talk about identity and heritage. The North Ndebele on their way to the Transvaal absorbed some people and were absorbed in different ways by other people. I was saying, you need to realise that these people are not self-contained tribes, they were mixing along the way. The Ndebele 20 years ago might have seen themselves as Shangaan or Pedi. Identity is not fixed or cast in stone. That caused a lot of debate. People say that if we look at the history of the Langa, their history is different from that of the Kekana, Mokopane, etc. The Langa went on a different route at a different time from the others. One activist said: 'You need to be careful. You might create the impression that some groups are senior to others.' I answered that I was not implying that the Langa was a junior group; simply that their history was different as a result of following a different route at a different time. The issue continued to be discussed over tea. As a historian you are going to disaggregate these identities and think about them in a more complex way, and you're bound to ruffle some feathers. You're dislocating their comfort zone. In my own research I am dismantling the myth of Ndebele unity. 
Erlank asks for clarification of what we mean by 'Heritage'. 'That can make my fingernails curl, if you mean cultural villages!' She then goes on to raise concerns about Heritage that intersect with other reservations expressed, pointing out that processes of selection employed in 'nation-building projects' often create the impression of favouritism and exclusion. 'Who selects the historians? This can skew perceptions of who's important in history and who's not.' She observes: 'It's tricky for people working in Heritage to maintain a critical edge against the need to produce a very rainbow nation kind of culture.' She describes feeling 'frustrated' by being dictated to by 'the moral imperative of struggle tourism'. But, she also fears that if Heritage fails it will take History down with it.

Some of her perceptions are derived from her experiences in teaching tourism. So, she describes the 'expectations' that people place on Heritage, raised by its potential value as a 'commodity':

If it fails to provide there will be a backlash against Heritage. Here we are, struggling to make people understand why History and Heritage are important in non-material terms. But, other people understand their importance in material terms because of commodification. If they [History and Heritage] don't provide, then it's going to make our project more difficult.

Mager is hesitant about commenting on the impact of Heritage on History. She describes Heritage as 'an applied domain associated with History,' and admits to having 'dabbled' in the field. She goes on to characterise Heritage as a 'foray' into History at this stage, distinguished by its 'cut-and-thrust politics' at different levels. She imagines that, given time, 'our preoccupation with Heritage as History will settle down'.

Grundlingh follows David Lowenthal's distinctions between History and Heritage, which are distinctly uncomplimentary to the latter. The idea that Heritage, since it can attract huge sums of money, will act as a 'panacea' to save the ailing discipline of History is dangerous if it means a seamless conflation of History and Heritage, Grundlingh warns. Like some of the other historians quoted here, he is anxious about the academic implications of 'South Africa [having] slipped into nation-building gear'. Like Lekgoathi, but using slightly different imagery, Grundlingh points to the 'grating' of gears for those who try to 'shift' from the 'disaggregating impulses of social history' to the 'conforming impulses that guide nation-building'.

Having pointed to the dangers that emanate from the growing Heritage industry, Grundlingh also wants to make it clear that he is not necessarily denigrating the academic study of Heritage. 'Studying Heritage can be more difficult than studying History.' He points to Leslie Witz's new book on the Van 
Riebeeck festival of 1952 as 'a new benchmark for how to approach public history'. ${ }^{4}$

Wright, like Nieftagodien, argues that historians have to adjust to the rise of Heritage. He points out:

Heritage Studies, as we all know, has grown very rapidly as a field of academic research and teaching in South Africa. Much of it, paradoxically, seems be quite ahistorical, and therefore uncritical, in its orientation. But the rise of interest in 'heritage', for a range of different reasons, on the part of the post-1994 state, big business, and the 'tourist public' is, for better or worse, an important political, social and economic phenomenon, and one that directly affects the future of the discipline of academic history. More and more, major elements of the country's past are likely to be defined by the operatives of the heritage industry; if academic historians do not adjust to this development, they will be even more sidelined in the wider society than they are already. The academic study of 'heritage' has the potential to open the discipline to major new ways of understanding what 'the past' is and how 'pastness' is made, as has been clearly demonstrated over a number of years now by historians at several South African universities, particularly the University of the Western Cape.

Witz, whose work in this area has been cited by several other respondents, says that 'Heritage has given people an opportunity to think about their work'. He then goes on to discuss several ways in which Heritage is being played out. First, he refers to what he calls 'an extension of the History Workshop - there is a sense that work may be disseminated more widely - that is an extension of the popularisation idea. There is a broader stage on which one can operate. Several historians have gone that route and done really interesting stuff.' Then there is what he describes as 'the negative counter-world of Heritage as something not to be engaged with, which refers to Lowenthal's [equation of Heritage with] lies, commercialism, succumbing to political power'. Like Nieftagodien, Witz observes that 'some people don't want to get dirty in the world of Heritage'. Lastly, he talks about the way that Heritage has influenced the writing of History:

A lot of material has been written about the heritage industry. It sees Heritage as Historical production. Heritage as something to be interpreted as a type of History. Historians are writing about it. Even if they are suspicious, they engage and criticise, like Jeff Guy, who has written about how tourist routes present a romantic version of Zulu history and the Anglo-Zulu War. ${ }^{5}$

4. L. Witz, Apartheid's Festival: Contesting South Africa's National Pasts (Bloomington, 2003); see also A. Coombes, History after Apartheid: Visual Culture and Public Memory in a Democratic South Africa (Johannesburg, 2004).

5. J. Guy, 'Battling with Banalities', Journal of Natal and Zulu History, 18 (1998). 


\section{The advent of democracy?}

For Nieftagodien, Lekgoathi, Ndlovu, Mathabatha, Erlank and Witz, this question was really answered in relation to some of the others. All expressed some degree of optimism, although Nieftagodien and Lekgoathi have been particularly disappointed by History's failure to take the post-1994 world by storm in quite the way it might have, given other post-colonial precedents. For a while, Lekgoathi confessed, he thought History might be extinguished altogether, and he is relieved to see it being rehabilitated.

Mager comments that History 'like everything else was affected by the advent of democracy in South Africa, which is as it should be'. Maylam believes:

The advent of democracy has taken away much of history's political significance in South Africa. As is well known, history was vital to white supremacism and Afrikaner nationalism - versions of the past were produced and taught to underpin those phenomena. It was also important to the liberation struggle, for which history could provide inspiration and guidance. In the post-apartheid era, the absence of any clear-cut causes to fight for or against has deprived history of its edge. While history should remain crucially important, studies of the past which have no obvious relevance to the present probably appear to many like the historical equivalent of 'blue sky research' - something which belongs to a firstworld country, but can hardly be funded in a developing country. This kind of thinking is regrettable, but symptomatic of neo-liberal discourse.

Grundlingh similarly describes a temporary retreat after 1994, since anti-apartheid historians found themselves at a loss for a 'persuasive political purpose', and neutral or pro-apartheid historians could hardly continue to 'flaunt' their earlier views.

For Etherington, like Lekgoathi and Nieftagodien, the advent of democracy should have had a huge effect on historical research and writing, but so far has not had much. 'The shrinkage of the core contingents of academic historians has not helped. It might also be remarked that histories of South Africa were democratised long before 1994. This may be one reason that the advent of democracy has changed very little.'

Wright argues:

The main effect of the advent of democracy on academic history in South Africa has been to sideline the discipline as a source of understanding the present. As political struggles against, and in defence of, white domination came to a climax in the 1970s and 1980s, Marxist and liberal-Africanist history teaching and research became important, at least in some universities, as ways of explaining what was taking place in the country. The number of students taking history courses rose rapidly. After 1994, with the rapid winding-down of political violence and the re-establishment of stability, public affairs in South Africa, to the great relief of the populace, became much less of a continual drama. Many people, perhaps most people, were only too happy to abandon 'history-as-taught' in favour of 'history-as-lived' (to use Jean Comaroff's apt phrasing), from history as pushed at them by 
politicians and schoolteachers and academics to history as they knew it from their own experiences. Contrary to the expectations of many, the policies of the new South African state also seemed to discourage public engagement with 'history as enquiry', except in the sphere of the state-sponsored Truth and Reconciliation Commission (which was clearly an embarrassment anyway to leading elements in the African National Congress), and to foster instead the embracing of a feel-good national 'heritage'. In the universities, as South Africa's political crisis dissipated, many students switched rapidly from courses which tried to teach understanding of fraught times to courses which held out the promise of teaching skills that would land them jobs and careers in the cut-throat world increasingly dominated by big corporations and the ideologies of the 'free market'. History suddenly seemed an irrelevance, and numbers taking history courses dropped sharply. This kind of turning away from the past is a feature of societies which have come through violent internal conflicts one only has to think of the examples of Germany, France, Italy and Japan after the Second World War, and Spain after its civil war. We can expect a couple of decades of being encouraged by our political elites to focus on the future before a new generation of citizens turns to asking critical questions about the past, and expecting answers from public figures.

\section{Has history become more Africanised since 1994?}

Grundlingh refers to Chris Saunders's point that History has been 'decolonised' for quite a long time. Addressing the question from its continental aspect, he refers to the considerations around South Africa's perceived exceptionalism, to which Mahmood Mamdani drew attention, ${ }^{6}$ and clearly supports the idea of extending an understanding of South Africa's past in a broader African context.

A matter of concern to Grundlingh is the demand for what he calls an 'essentialist national African voice' to be heard in new history writing, which easily slips into an assertion that 'only black people can write black history'. In this connection, he refers to Eugene Genovese's response: 'there is no such thing as a black theology, or a black point of view'. This statement is a prelude to a plea for allowing a 'multiplicity' of African voices to speak, which Grundlingh fully endorses, and he anticipates the healthy impact of a 'fresh cohort of academics'.

Grundlingh makes his comments against a detailed knowledge of how few black members of staff there are in university History Departments, and agrees with policy statements that call for a radical change. Well aware of the feelings of insecurity experienced by those who worry that they are about to be made 'extinct' by policy objectives such as those that have emanated from the South African History Project, which deplore the 'current white and largely male domination of the South African historical profession', Grundlingh advises white male historians not to read this as an 'indictment of their intellectual contribution'. White male historians, he maintains, should be able to recognise the 'historicity' that once worked in their favour during the 'extraordinary growth' of the profession

6. M. Mamdani, Citizen and Subject: Contemporary Africa and the Legacy of Late Colonialism (Kampala, 1996). 
nurtured by the structural conditions of the 1980s. Not that, he cautions, there is a 'phalanx' of young black historians ready to take their place. Unfortunately, too many black students with the potential to become academics are still lured to the 'boardroom' rather than the 'lecture room'.

Mathabatha also calls for more Africanisation and for more 'South African black historians'. Erlank wishes that History could attract more black women specifically. She is slightly uncertain of what we mean by 'Africanisation', and takes her cue from some of the interpretations offered by other respondents. She focuses on the continental question, pointing out that her work in gender studies has brought about a great deal of continental contact. 'I don't feel I'm out of touch with Africa. I teach quite a lot of African stuff. What I wish for is that black students would write about whiteness.'

Witz asks:

Do you mean have we taken up Mamdani's challenge? I remember the Peires-Ranger debate about how African historians would change the face of South African History? ${ }^{7}$ Well, it didn't. However, more and more students from the rest of Africa are coming to South Africa. I think that a substantial number of our courses are focused on the continent as a whole. Here I am thinking of courses that we run at second and third year, such as 'Africa, Race and Empire', and 'Africa since Independence'. On the whole, there hasn't been a substantial engagement. But it does take place in Heritage. Students are coming from other parts of Africa and we are making contacts in other places.

Where are the black historians? I think they are there. Many students have come through Public and Visual History and have gone into posts in government departments or museums. I do define them as historians. There are so few [university] posts in History, and so we almost go round and round in a circle. The SADET volume ${ }^{8}$ presents itself as the 'lions have now written their history'. ${ }^{9}$ Black historians are writing and they are substantial in this project, which is strongly academically informed, but are generally not within the bounds of university departments. There are exceptions. Martin Legassick did run the Western Cape Project at UWC. Jabu Sithole at UKZN has done major work on this project as well. One new historian whose work I really like is Nsizwa Dlamini, who is working on the politics of museums and memorials in Kwazulu-Natal.

Like Erlank, Witz comments on the paucity, with a few notable exceptions, of black women historians.

7. J.B.Peires, 'Suicide or Genocide? Xhosa Perceptions of the Nongqawuse Catastrophe', Radical History Review, $46 / 7$ (1990), 47-57; J.B. Peires, 'A Usable Past', Southern African Review of Books (July/Oct. 1991); T. Ranger, 'Audiences and Alliances', Southern African Review of Books (May/June 1991), 5.

8. South African Democracy Education Trust, compilers, The Road to Democracy in South Africa, Volume I: 1960-1970 (Cape Town, 2004).

9. This is a reference to the proverb about how it is usually the hunters rather than their prey that get to write History. 
Nieftagodien considers the meanings of 'Africanised' both in a South African and continental sense, and worries that the dominant narrative of African history will take on a pessimistic hew at schools. Although, he cautions, one does not want to go 'looking for the Renaissance around every corner'. Once again he makes a plea for critical history.

Lekgoathi's ideas on Africanisation flow into what he has to say about paradigm shifts, and are dealt with to some extent in the relevant question below (see pp 19-20). Drawing attention to arguments that Sifiso Ndlovu had made in his presentation on the Soweto Uprising at the Townships Now symposium, ${ }^{10}$ Lekgoathi stresses the importance of having accounts written from 'our perspective as participants. We understand the language. This time round we are not the research assistants. We are much more likely to tease out some of the cultural nuances.'

Ndlovu himself is quite adamant that History has not been Africanised after 1994. He argues: 'If History was Africanised at university level we would, for instance, have produced more students who specialise in the different fields of 'precolonial or pre-contact' history ... and who are competent in terms of using indigenous African languages.' A tally of 'African historians and students who have doctorates or who are presently registered for a $\mathrm{PhD}$ degree specialising in precolonial history' delivers disappointing results. 'I cannot even count up to five.'

With a certain amount of scepticism, Ndlovu notes the inclusion of Africa in the school curricula. He suspects it may be a 'futile exercise because the majority of school teachers are not well-versed in this component - they were badly trained and the lack of good History textbooks and teaching material also exacerbates the situation'. He hopes that the agreement with UNESCO and the South African History Project (of which he was a member), which resulted in the latter acquiring the rights to eight volumes of the UNESCO History series on Africa, including a special teachers' guide written by Dr June Bam, might help to remedy the problem in the long term. The books are currently being distributed throughout the country, but Ndlovu is still doubtful about whether this 'commendable effort' can 'address the existing problem about the teaching of African history in the classroom'.

Etherington, similarly, takes quite a strong, oppositional view: 'History has not become more Africanised post-1994. The shift of emphasis in scholarly circles away from "history from below" to history from above (in the form of close textual analysis) has moved Africans out of the picture in much historical writing.' And Maylam adds:

The Africanisation of South African history reached its high point in the two decades before 1994. In the 1970s and 1980s there appeared original studies of African states and chiefdoms in the pre-industrial era; African resistance and political struggle became significant

10. This symposium was hosted by WISER, University of the Witwatersrand, 2004. 
themes; and the main focus of urban and rural history was on African communities. There is little evidence that African history has become more Africanised in content since 1994 - although that may change if Afrocentrism takes hold in the country.

\section{Have there been any new paradigm shifts lately?}

Witz maintains that it is difficult to think of major paradigm shifts having occurred. 'There has been an encounter with the production of History, but there hasn't been a substantial encounter with subaltern or postcolonial studies.' Many of the other respondents variously expressed their astonishment or relief at how slight this 'encounter' has been.

In considering areas where there have been surprising absences, Witz acknowledges the work of his colleague Premesh Lalu who used the story of Nicholas Tilana Gcaleka who went in search of the skull of Hintsa to theorise the implications of the nature of History after apartheid. " History has become "more inclusive, with under classes and so on - but this is more of an additive. No one has thought through the implications of what History is after apartheid.' On further reflection, Witz says:

I suppose the closest that we have come to a paradigm shift is the way that material that used to be regarded as sources of history are now being considered as histories in their own right. I am thinking here particularly of oral and visual history where the interview and the photograph are no longer simply treated as evidence ... They are increasingly seen as specific ways of producing history with their modes and conventions and it has become important for us to understand the contexts of their production and circulation.

Unsurprisingly, but like almost all the other respondents, Witz also alludes to "the shifts linked to Heritage' and, in keeping with how he responded to the first two questions, reiterates that it is 'History on a wider scale'.

Grundlingh mentions Heritage and Public History, calling them 'slightly different paradigms', but doubts that they 'impinge much on History as we have it'. He also refers to trends in Cultural Studies, particularly post-modernism and the 'post-colonial challenge', but observes that their impact, apart from Clifton Crais's works, ${ }^{12}$ has 'not been as dramatic as one would have expected'. Grundlingh criticises approaches in Cultural Studies that are centred exclusively on the text, pointing to their failure to ask 'why this text at this particular historical juncture?' He singles out Isabel Hofmeyr as an exception in the field of literary/cultural studies, since her textual analysis always has 'a good historical grounding'. Grundlingh points out that historians have not needed to be told that

11. P. Lalu, 'In the Event of History' (PhD thesis, University of Minnesota, 2003).

12. C. Crais, White Supremacy and Black Resistance in Pre-Industrial South Africa: The Making of the Colonial Order in the Eastern Cape, 1770-1865 (Cambridge, 1992); C. Crais, The Politics of Evil: Magic, State Power and the Political Imagination in South Africa (Cambridge, 2002). 
their discipline is a 'discursive one,' and that evidence must be read within its particular context. He also worries about the emphasis that 'post-modernist thinking' tends to place on 'difference', observing that 'neo-marxian social history' did have a 'blind spot' as far as culture was concerned, especially in its 'more rigid' class analyses, but that 'one equally has to be aware of the negative side of an overemphasis on ethnic culture and cultivating "difference", particularly in South Africa'. Here he refers to Norman Etherington's argument that 'the opacity of otherness' in some post-modernist texts allows for the resurrection of the 'intellectual ghost of apartheid'. ${ }^{13}$ Grundlingh refers to Indian subaltern studies as a useful, if imperfect, model for an approach that "incorporates "difference" without allowing it to dictate'.

Mathabatha believes that there have been paradigm shifts, with a 'much more inclusive kind of urban history focusing on the townships and informal settlements'. He regrets the fact that the 'homelands and rural villages are being ignored'.

Nieftagodien sounds a bit nostalgic for the critiques of a decade or so ago, which engaged with the frailties of History as a discipline, and its perversion as 'official history'. 'They gave a particular perspective questioning the discipline itself. My sense is that this critique has dissipated somewhat because these people have moved on to a focus on myths, monuments and festivals.' He notes the proliferation of biographies, which he would not classify as a paradigm shift, but some of which are capable of providing genuinely new perspectives on particular decades. For example, he cites Our Generation by Zubeida Jaffer, pointing out that it could only have been 'written by a Muslim woman with a child'. ${ }^{4} \mathrm{He}$ is disappointed by the reappearance of 'Great Man history' camouflaged as the history of the struggle:

Go to the bookshop and you'll see mostly political history and 40 per cent is about Mandela. It's a product of the transition - political history - and we can't escape the iconic status of Mandela, which reinforces Great Man history. There was an old critique of Great Man history, now just because it's black it's $O K$.

Nieftagodien appears to vacillate between mourning the death of the kind of radical history that attracted him as an undergraduate, and the sense that something new is building up. Thus he notes 'other shifts that have evolved and then dissipated', for example, the greater emphasis on race and identity after 1994 which peaked with the 'Burden of Race' conference at the University of the Witwatersrand in 2002 , but which no longer appears to be such an 'intense' preoccupation, although, no doubt, it will 'continue to generate historical interest resurrecting indigenous cultures, linked to Heritage'. He also remarks that 'a lot

13. N. Etherington, 'Postmodernism and South African History', New Contree, 41 (Nov. 1996).

14. Z. Jaffer, Our Generation (Cape Town, 2003). 
of exciting things are happening, but in the past ten years there has been nothing profoundly spectacular'. He mentions the TRC and Heritage debates around memory, but reiterates that, for the moment, History has lost its 'cutting edge of social critique'. 'History as a discipline should and can contribute to our society developing a better, more nuanced understanding of itself. We haven't moved beyond the broad brush-strokes. Generally we see ourselves through the prism of the rainbow.' But he pursues the promise of the 'intellectual issues that are around [which may] coalesce at some point'. 'Maybe,' he says, 'we're doing the groundwork. Maybe people felt like that in the 1960s.' Could it be, he wonders, that slogging through the townships doing the empirical work, will really turn out to be the foundation of something spectacularly new? Nieftagodien tends to believe that we need 'quantitative accumulation in order for there to be qualitative leaps'. The 'wealth of collective memory' is still relatively untapped, and should be assiduously recorded because 'in ten to 15 years time a whole generation won't be with us and we'll be left only with the two nationalist narratives'. Perhaps a new generation capable of asking the 'interesting' questions will rise up and make use of the 'raw material' we have harvested.

Maylam objects to implicit assumptions that 1994 might have special significance in terms of paradigm shifts in South African history:

What can loosely be called 'post-theoretical' approaches were coming to bear on the discipline before 1994. There has been a growing interest in representation, memory and discourse - this, though, is not connected to the end of apartheid, but rather to international intellectual influences. Similarly the critique of Marxist history - especially its more reductionist, determinist strand - long predated 1994. It is regrettable that the insights of materialist analysis have been so readily discarded. It is also strange that this should have happened in a neo-liberal age when global capital exercises such power.

In similar vein, Etherington sees no significant paradigm shifts since 1994. 'Most historians adhere to positions staked out in theoretical debates of the $1960 \mathrm{~s}$, whether materialist or post-structuralist. Social history is alive and well, but very little ground-breaking work in that field post-1994 has seized the imagination of historians.'

Lekgoathi points out that black historians are still constrained, to an extent, by existing paradigms because they constitute the benchmarks for publication and the award of senior degrees. 'We have to show our understanding of existing paradigms and that shapes what we can say about where we're coming from. But we're not completely regurgitating established paradigms.' Lekgoathi uses two examples - one from Isabel Hofmeyr's work on oral stories about the siege in the Cave, ${ }^{15}$ and one from Peter Delius's study of youth revolt in the 1980 s in

15. 1. Hofmeyr, We Spend our Years as a Tale that is Told: Oral Historical Narrative in a South African Chiefdom (Johannesburg, 1993). 
Sekhukhuneland, ${ }^{16}$ to suggest that a more subtle understanding of the language might deliver slightly different readings from those proposed by historians who do not speak an African language as their mother tongue. Lekgoathi stresses that he is not saying that only Africans can write good African history. But being a 'cultural insider' can make it easier to detect certain nuances. He is also aware of how being a

product of the western Academy puts me apart from the people I'm writing about. I'm educated, I'm part of the elite. I articulate my views to you in English. Many of the people can't do that. They speak only North Ndebele and North Sotho. I'm also a man and so I can't broach certain subjects with my female informants. I'm young and most of my informants are old people. I'm an outsider on that level.

Erlank says: 'I'm not sure I'm able to answer that question [about paradigm shifts] generally. It's difficult to keep up, and increasingly so with teaching burdens and more journals. It's much more difficult to have an overview of what's going on in History.' For her the workload also 'contributes to the parochialism' of History Departments, which is a disturbing element of the state of the discipline today: 'In the last couple of years there has been a move back to understanding nationalism and identity in different ways than before. When I started at varsity there were a couple of pieces that were key readings, one of which was Leroy Vail's Creation of Tribalism. ${ }^{17}$ We've moved away from that, but are approaching identity politics in a new way.' Echoing Nieftagodien's fears about the revival of Great Man history in a new guise, she says: 'I regret a tendency I see in students' association with a masculinist approach concerned with political leadership (I use the term 'leadership' advisedly) - with top-down structures.'

Erlank noted how hard it was to keep working on the nineteenth century in isolation, and was encouraged to talk about her newer work on 'sexuality and its contribution to African national identities in the early twentieth century - the role of custom and modernity in the creation of national identity. My study of modern versus traditional attitudes to sex is part of a broader project.' She is also working on more contemporary interpretations of gender: ' ... the way the understanding of gender has shifted in the ANC in the last 10 years, and what people understand by gender. There are some similarities between the earlier work and this project. Both are about citizenship, identity and national politics.' She makes the point that 'paradigm shifts are not just about intellectual shifts, but also about political shifts - responding to the political moment'. Nieftagodien saw it rather as the peaking of a particular trend, which then terided to fall off, Erlank described the 'Burden of Race' conference as the catalyst of a shift.

16. P. Delius, A Lion amongst the Cattle: Reconstruction and Resistance in the Northern Transvaal (Johannesburg, 1996).

17. L. Vail, ed., The Creation of Tribalism in Southern Africa (London, 1989). 
Mager thinks that 'History's reluctance to learn from literature and theory has softened, sometimes to good effect and often with deleterious consequences'. She also notes that 'economic history has broken out of its rigid Marxist economism, and exciting new studies employing the techniques of deconstruction and new theories make interesting reading'.

Ndlovu's views provide striking contrasts to those of some others. $\mathrm{He}$ believes that there has been a significant paradigm shift:

Africans are now the subjects of the historical narrative. Social history, public history, local histories, gender histories and different voices are clamouring to be heard... Different methods and methodologies are being utilized in this respect - oral history and visual history are becoming useful tools. The question of race is still important, and this should be the case.

As far as post-modernism is concerned, he observes that we "do not have to follow' countries such as the USA and Britain, since 'we have hardly modernised', which makes it slightly premature to talk about post-modernising. He recalls:

I found this a turn-off when driving from Soweto to Vista University in Sebokeng during the early $1990 \mathrm{~s}$ - passing through all those squatter camps along the Golden Highway, and then on campus you meet some of your colleagues who are only interested in debates about post-modernism - teaching students, some of whom are from the squatter camps and use candles for studying.

Ndlovu acknowledges that historians may have something to learn from familiarising themselves with post-modernist debates, but pursuing these debates is best left to those who choose career paths as literary theorists. Like Grundlingh and Maylam, Ndlovu makes several observations about how conscious historians have been of the need to interrogate the methods of their discipline for a fairly long time:

To accuse historians of being oblivious to difficulties posed by their discipline is unfair. There exist publications authored by historians on the 'problems of History', the 'nature of History' and so on, which date back to the early twentieth century and are used as reading material ... in historiography courses.

\section{Gap between professional historians and historians on the outside?}

Grundlingh observes that this has been 'playing itself out' in Stellenbosch recently with a Coloured community that was forcibly removed. 'They're Afrikaners and have been cold-shouldered by fellow Afrikaans-speakers.' He explains that members of this community are currently going through a kind of Write Your Own 
History exercise, using oral interviews. ${ }^{18}$ 'They insist on having a place in history, to say "we were here".' But, he goes on to say that, in terms of writing History, what they say cannot be 'left in an unmediated' form. He acknowledges that there are inevitable tensions between professional and popular historians, but thinks they can be 'mutually enriching'. 'It can be a fruitful, creative tension.'

Ndlovu thinks that 'practitioners from outside the profession' should be welcomed 'provided they are prepared to acknowledge the fact that there are professional standards and rules to be upheld by History teachers (at school level), and History lecturers at universities - including those like myself who are practising professional historians outside the institutions of learning'. Professional medical practitioners, lawyers or accountants are held accountable to particular standards and 'so I see no reason why professional historians and history practitioners should not call for the maintenance of professional standards'.

Mathabatha finds it frustrating that professional historians do not recognise non-academic historians as historians and do not recognise non-academic histories either. 'Some of their [non-academic historians'] work is utilised in publications without being acknowledged by academic historians.' Lekgoathi takes up a similar point with an illustrative anecdote, after noting frequent encounters with people "who have collected a lot of information and tell you: "I've done so much research, I actually have a manuscript in my cupboard".' He describes an old man who had worked as a research assistant to a government ethnologist, who subsequently used the old man's material in a publication without acknowledgment. As a consequence, Lekgoathi found that the old man 'couldn't really open up completely because of the way he's been exploited in the past. "My cupboard is full of information but I don't trust researchers. They steal your things and you never see them again".'

Erlank was not asked this question directly, but at one point in the interview she turned the tables on the interviewer, saying: 'Let me ask you a question now. Is History in your Department interdisciplinary?' After a brief discussion she concluded with a sentiment that might account for the kind of professional possessiveness both Mathabatha and Lekgoathi describe above: 'Historians are frightened of losing limbs to body snatchers from other disciplines. They have this thing about what is proper History.'

Witz observes that we might be talking about historians who 'take up posts outside the academy which is good', and realistic in terms of encouraging students to think that they will get jobs after graduation. But then, he argues, we need to ask how we engage with historians who have not been trained in universities. Drawing on the example of historians' attempts to engage with the 'Zulu' politics of the 1980 s, Witz reminds us of how fraught such engagement may be. 'A whole set of dynamics and politics makes it difficult. We have to be quite strategic and projects 
need to be well-thought through before engaging.' Witz advises that we ask of projects in which professional historians and others have collaborated: 'What sort of History has been produced? How has the engagement worked itself out?' 